\title{
Implementation of Computer Assisted CIPP Model for Evaluation Program of HIV/AIDS Countermeasures in Bali
}

\author{
I Made Sundayana \\ Director/Lecture of Health Education \\ Buleleng School of Health \\ Bali, Indonesia
}

\begin{abstract}
One of the fact within economical development of tourism in Bali is indicated by established tourism facilities in order to support Bali tourism industry. Consquently, It has brought up effect that large numbers of new citizen search for occupation to Bali.Those people who came and settle in Bali temporaly or permanently, consequently Bali become heterogeneous.Thus, Bali become over populated. Since, over populated in Bali has risen up the economic sector and it has been spreading HIV /AIDS rapidly. As anticipation and prevention for contagious, developed and spreading HIV of Bali Provinse has regulated (regional act) Number 32006 concerning of prevention act fr HIV/AIDS. As the matter of fact, regional act is not properly conducted yet as, therefore it is evaluation required for the rule and program that have been conducted by the government.One of the technical evaluation can be applied is CIPP model. However, CIPP model is still applied in conventional way and it has not yet contributed accurate evaluational count in processing the data, therefore by using CIPP model of computer assistance. This can be proved by ending up the result of the total program percentage of HIV /AID

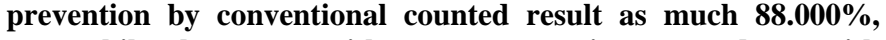
meanwhile the count with computer assistance end up with $\mathbf{8 8 . 4 0 0 \%}$ in result. It shows high category.
\end{abstract}

\section{Keywords-Evaluation; Computer Assisted CIPP Model}

\section{INTRODUCTION}

Tourism sector is a significant sector in order to achieve regional revenue goverment income.Tourim shall be perceived from several point of view as its complexity embedded within tourism activity. Among of those activity are tourism as resource, tourism as business, and toursm as industry. Those things indicate that tourism has potential in order to support economic sector.

One of the reality in economy base on develoving of Bali's tourism is facilities that had been established as an effort to support Bali Tourism. By Having established various of business, consequently, new comers have come to seek occupations. Pople who came to settle permanently or temporally having social interaction with local that creating heterogen society. Heterogenity is causing over populated in Bali, however it's rising up economy sector as well as spreading infected desease HIV/AIDS.

Masiive spreading of HIV/AID indicates high rate of infection. In Bali particularly HIV/AIDS infected not only in urban but also in rural. Large numbers of HIV/AIDS cases rose in rural . Until nowdays, the process of preventing HIV/AIDS structurally involves formal institutions, and traditional instutions yet socialized in rural based on geographical reason and daily activity of the traditional society.

On other side, effort to prevent HIV/AIDS consider the government policy voint of view, whereas the HIV/AIDs's subject and object is it's own. Various action of anticipation or prevention of spreading and contagious HIV/AIDs, Bali Province has Local Act Number 32006 regarding HIV/AIDS, however the provision is unble to well manage, therefore it is necessary to evaluate the act program which is conducted by the government.

One of the technical evaluation applied is CIPP model, However, CIPP model that has been applied conventionally yet shows accurate counted evaluation in processing its data.

It is appropriate on the results of research conducted by Dewa Gede Hendra Divayana about Program Evaluation of Management E-learning shows the model is done in the conventional CIPP still not provide an accurate evaluation calculation of the data processing[1]. From the results of these studies, the authors are interested in continuing the development of conventional CIPP model evaluation toward a computer assisted CIPP model.

\section{LITERATURE REVIEW}

\section{A. Evaluation}

In [2], Evaluation is a mean for understanding how things going.

In [3], Evaluation can be defined as the determination of conformity between the results achieved and the objectives to be achieved.

In [4], Evaluation can be defined as an activity or process to provide or specify a value above a certain object, things, institutions, and programs.

In [5], evaluation is a systematic and ongoing process to collect, describe, interpret and present information about a program to be used as a basis for making decisions. 
From the opinions of the above can be concluded in general that the evaluation is an activity in collecting, analysing, and presenting information about an object of research and the results can be used to take a decision.

\section{B. CIPP Model}

In [6], the core concept of this model denoted by the CIPP acronym, which stands for the evaluation context, input, process, and product.

In [7], the CIPP evaluation there are four components that must be passed is the evaluation of the component context, the evaluation of input component, the evaluation of process components, and the evaluation of product components.

In [8], the CIPP model evaluation consists of four types, namely: context evaluation, input evaluation, process evaluation and product evaluation.

In the evaluation context is carried out to identification and assessment of the needs that underlie the program formulation. The input evaluation carried out to choose among several existing planning. In the process evaluation is carried out to access the implementation of the plan has been set. And the product evaluation conducted to identify and access the outputs and benefits of a program.

In [9], basically the CIPP evaluation model requires that a series of questions will be asked about four different elements of the model on the context, input, process, and product.

From the above opinions can be concluded in general that the CIPP model is a model in its activities through four stages of evaluation are: evaluation of the component context, input, process and product.

\section{Methodology}

A. Object dan Research Site

1) Research Object is HIV/AIDS countermeasures program.

2) Research Site at Health Department of Bali Province.

\section{B. Data Type}

In this research, the authors use primary data, secondary data, quantitative and qualitative data.

\section{Data Collection Techniques}

In this research, the authors use data collection techniques such as interviews, observation, and documentation.

\section{Analysis Techniques}

Analysis techniques used in this research is descriptive statistical.

\section{E. Aspect of Evaluation}

The aspects evaluated in HIV/AIDS countermeasures program can be seen in Table I bellow.
TABLE I. EVALUATION CRITERIA

\begin{tabular}{|c|c|c|}
\hline No & Component & Aspects \\
\hline \multirow{3}{*}{1.} & \multirow{3}{*}{ Context } & Local regulations of HIV/AIDS \\
\hline & & The mission and purpose of program \\
\hline & & $\begin{array}{l}\text { Readiness from Head of Health Department in } \\
\text { implementing the regulations of HIV/AIDS }\end{array}$ \\
\hline \multirow{3}{*}{2.} & \multirow{3}{*}{ Input } & Guide of the program implementation \\
\hline & & Human resources \\
\hline & & Facilities and infrastructure \\
\hline \multirow[b]{2}{*}{3.} & \multirow[b]{2}{*}{ Process } & Program planning of HIV/AIDS countermeasures \\
\hline & & $\begin{array}{l}\text { Program implementation of HIV/AIDS } \\
\text { countermeasures }\end{array}$ \\
\hline \multirow{2}{*}{4.} & \multirow{2}{*}{ Product } & $\begin{array}{l}\text { The impact of implementation of HIV/AIDS } \\
\text { countermeasures program }\end{array}$ \\
\hline & & $\begin{array}{l}\text { The expected outcome form implementation of } \\
\text { HIV/AIDS countermeasures program }\end{array}$ \\
\hline
\end{tabular}

\section{RESUlt AND Discussion}

A. Result

The research results can be seen in Table II below.

TABLE II. EVALUATION RESUlts OF Hiv/Aids COUNTERMEASURES PROGRAM WITH CIPP MODEL IN CONVENTIONAL

\begin{tabular}{|c|c|c|c|c|c|c|c|c|c|}
\hline \multirow[b]{2}{*}{ No } & \multirow[b]{2}{*}{ Dimension } & \multirow[b]{2}{*}{ Aspects } & \multicolumn{5}{|c|}{ Respondents Score } & \multirow[b]{2}{*}{$\mathbf{X}$} & \multirow[b]{2}{*}{$\%$} \\
\hline & & & R1 & $\mathbf{R 2}$ & R3 & R4 & $\begin{array}{l}\mathbf{R} \\
\mathbf{5}\end{array}$ & & \\
\hline \multirow[t]{3}{*}{1.} & Context & $\mathrm{C} 1$ & 5 & 4 & 5 & 4 & 4 & 4.4 & 88 \\
\hline & & $\mathrm{C} 2$ & 5 & 4 & 4 & 5 & 5 & 4.6 & 92 \\
\hline & & $\mathrm{C} 3$ & 5 & 4 & 4 & 4 & 5 & 4.4 & 88 \\
\hline \multicolumn{9}{|c|}{ Percentage of Effectiveness on Context Dimension } & 89 \\
\hline \multirow[t]{3}{*}{2.} & Input & I1 & 5 & 5 & 4 & 5 & 5 & 4.8 & 96 \\
\hline & & $\mathrm{I} 2$ & 4 & 5 & 5 & 4 & 4 & 4.4 & 88 \\
\hline & & I3 & 5 & 4 & 4 & 5 & 4 & 4.4 & 88 \\
\hline \multicolumn{9}{|c|}{ Percentage of Effectiveness on Input Dimension } & 91 \\
\hline \multirow[t]{2}{*}{3.} & Process & P1 & 4 & 4 & 4 & 4 & 5 & 4.2 & 84 \\
\hline & & P2 & 4 & 5 & 5 & 4 & 4 & 4.4 & 88 \\
\hline \multicolumn{9}{|c|}{ Percentage of Effectiveness on Process Dimension } & 86 \\
\hline \multirow[t]{2}{*}{4.} & Product & $\mathrm{O} 1$ & 5 & 4 & 4 & 5 & 4 & 4.4 & 88 \\
\hline & & $\mathrm{O} 2$ & 4 & 5 & 4 & 4 & 4 & 4.2 & 84 \\
\hline \multicolumn{9}{|c|}{ Percentage of Effectiveness on Product Dimension } & 86 \\
\hline \multicolumn{9}{|c|}{$\begin{array}{c}\text { Total Percentage of Effectiveness } \\
\text { Category }\end{array}$} & 88 \\
\hline & & & egor & & & & & & High \\
\hline
\end{tabular}

Explanation :

C1 : Local regulations of HIV/AIDS

$\mathrm{C} 2$ : The mission and purpose of program

C3: Readiness from Head of Health Department in implementing the regulations of HIV/AIDS

I1 : Guide of the program implementation

I2 : Human resources 
I3 : Facilities and infrastructure

P1 : Program planning of HIV/AIDS countermeasures

P2 : Program implementation of HIV/AIDS countermeasures

O1: The impact of implementation of HIV/AIDS countermeasures program

$\mathrm{O} 2$ : The expected outcome form implementation of HIV/AIDS countermeasures program

$\mathrm{X}:$ Average

$\%$ : Percentage

Category of scale effectiveness:

Highest : $90 \%-100 \%$

High : :80\%-89\%

Sufficient : $70 \%-79 \%$

Low $: \leq 69 \%$

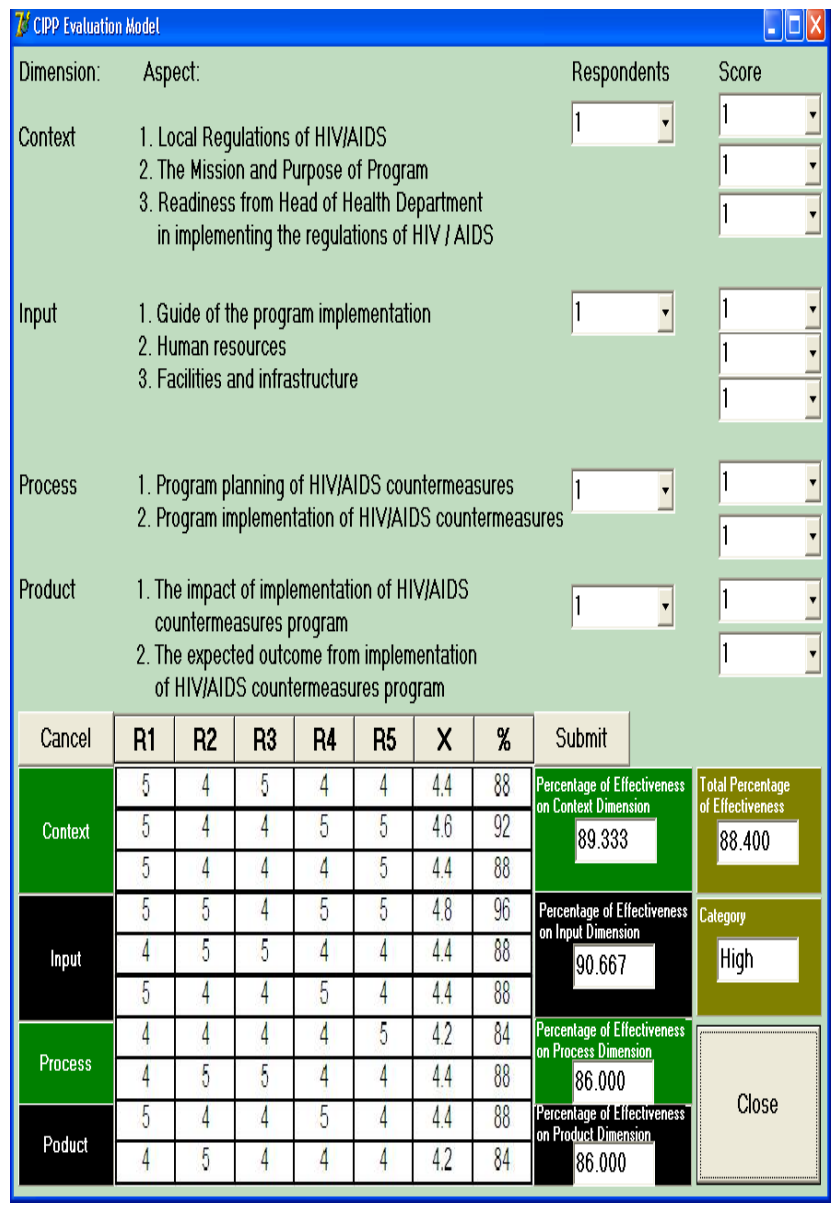

Fig. 1. Evaluation Results of HIV/AIDS Countermeasures Program With Computer Assisted CIPP Model

From the above results can be seen clearly that the results of the evaluation by Computer Assisted CIPP model calculation shows the results more accurate than using the conventional calculation method. It is seen from the results the percentage of effectiveness on context dimension with the conventional calculation shows result of $89.000 \%$, while the computer aided calculation shows result of $89.333 \%$. The percentage of effectiveness on input dimension with the conventional calculation shows result of $91.000 \%$, while the computer-aided calculation shows result of $90.667 \%$. The percentage of effectiveness on process dimension with the conventional calculation shows result of $86.000 \%$, while the computer-aided calculation also obtained the same result of $86.000 \%$. The percentage of effectiveness on product dimension with the conventional calculation shows result of $86.000 \%$, while the computer-aided calculation also obtained the same result by $86.000 \%$. The Total Percentage of Effectiveness of HIV/AIDS countermeasures program with the conventional calculation shows result of $88.000 \%$, while the computer-aided calculation shows result of $88.400 \%$ with the higher category.

\section{CONCLUSIONS}

There is concusion to be drawn from this research that by applying CIPP evaluasion model based on computer assistance shall achieve more accurate and rapid counting compare to conventional way of counting. There after, decicion maker shall be quicker in order to make recomandation within decicion making whether the program shal be terminated or be proceded.

\section{ACKNOWLEDGMENTS}

The author express their gratefulness to staff at Buleleng School of Health for all support and motivation. The author also generously thank to Dewa Gede Hendra Divayana, Ph.D. as Lecture at IT Education, Informatics Department, Ganesha University of Education.

\section{REFERENCES}

[1] D.G.H. Divayana. Program Evaluation of Management E-learning (Thesis). Surabaya: YAPAN Surabaya School of Economic, 2014.

[2] L.H. Kuo, et.al., "An Evaluation Model of Integrating Emerging Technology into Formal Curriculum," in The International Journal of Education and Information Technologies Vol.6, No.3, 2012,pp.250-259.

[3] D. Mardapi, Measurement, Assessment, and Evaluation of Education ( $1^{\text {st }}$ Edition). Yogyakarta: Nuha Medika, 2012.

[4] S. Rutoto, "Observing the Guidance and Counseling Program Evaluation at School Present and Future," in Mawas Vol.1,No.1, 2010,pp.1- 15.

[5] H. Sundoyo, T. Sumaryanto, Dwijanto, "Program Evaluation of Dual System Education Based of Countenance Stake Model," in Innovative Journal of Curriculum Vol.1,No.2,2012,pp.69-73.

[6] D.L. Stufflebeam, C.L.S. Coryn, "Evaluation Theory, Models, and Applications (2 ${ }^{\text {nd }}$ Edition). San Francisco: Jossey-Bass, 2014.

[7] Wirawan. Evaluation Theory, Model, Standards, Applications, and Profession ( $1^{\text {st }}$ Edition). Jakarta: Rajawali Pers,2011.

[8] M. Tiantong, P. Tongchin, “A Multiple Intelligences Supported Webbased Collaborative Learning Model Using Stufflebeam's CIPP Evaluation Model," in International Journal of Humanities and Social Science Vol.3, No.7,2013,pp.157-165.

\section{AUTHORS BIOGRAPHY}

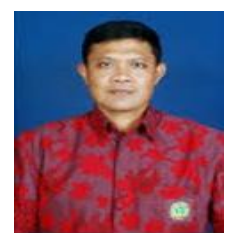

Ns. I Made Sundayana, S.Kep., M.Si. was born in Cipanas, West Java, in 1969. He worked as Director and also Lecture at Buleleng School of Health, Buleleng, Bali. Now, he is completing doctoral program studies at Jakarta State University. 